\title{
Cooperative Patterns in the Egyptian Colloquial Arabic
}

\author{
Siti Aminah, Amir Ma'ruf \\ Universitas Gadjah Mada \\ Email: aminah_arb@ugm.ac.id
}

\begin{abstract}
This article described the cooperative patterns formed in the Egyptian speech community using Egyptian Colloquial Arabic (ECA). The data were taken by using participatory observation method through the recording and note-taking techniques. By employing Grice's theory of cooperative principles and maxims, this study suggested that speech events in Egyptian society had a variety of cooperative patterns. The varied patterns could be seen in the negotiation processes to reach an agreement. Therefore, the negotiations required a lot of energy and time.
\end{abstract}

Keywords: $E C A$, speech, cooperative pattern

\section{INTRODUCTION}

Speakers and listeners involved in conversation are generally cooperating with each other (Yule, 1996:63). As suggested by Wijana (1996:46), there is some sort of cooperative principle to do by both speaker and listener so that the communication process runs well. Therefore, cooperative principles in a conversation should be understood by each interlocutor, no exception for people who speak Arabic as a second language (Sobh, 2013:150).

In communication, the speaker articulates certain utterances with the intention to communicate something to his/her interlocutor and hopes he or she understands what are going to be communicated. Therefore, the speaker is always trying to make their utterances always relevant to the context, clear, understandable, succinct, concise and to the point, so that they do not spend their interlocutors' time much (Wijana, 1996:45).

The Egyptians communicate by using Modern Arabic which consists of Modern Standard Arabic (fusha) and Egyptian Colloquial Arabic (amiyah). This is consistent with Prochazka (2006) and Greis (2000) who stated that Arabic has two varieties, i.e. fusha and amiyah. Modern Standard
Arabic (fusha) is used in writing and in most formal speech, including in academic lecturers (Bakalla, 1984:81). Meanwhile, the amiyah variety, also known as Egyptian Colloquial Arabic (ECA), is used by the Egyptians in daily conversation and non-formal situations. Like the process of communication in general, in a conversation, the speaker and the hearer mutually realize that there are rules that guide their actions, use of language, and interpretation of the partner's utterances and deeds (Wijana, 1996:45). Consequently, both speaker and hearer create cooperative patterns during their communication. Therefore, this study examined the cooperative patterns that were formed by speakers and hearers in their conversations using ECA.

Jaradat (2011:243) investigated the pragmatic function of intonational variations in a Jordanian dialect spoken in Irbid. The study discussed the intonational variations in different utterances with directive and commissive illocutionary forces. The illocutionary forces examined in this study were: orders, requests, warning, threatening and promising. By using the autosegmental-metrical approach which was proposed by Pierrehumbert (1980), the study showed that intonation changes 
the interpretation of an utterance by virtue of its structure into another interpretation which the speaker actually intends to convey. Also, intonation is needed to determine the illocutionary function of an utterance when there is no any other illocutionary marker. In a same speech community, Sobh (2013:150) investigated apology as a way to express politeness. His study focused on the expressions of apology used by Jordan university students. The findings showed that the apology strategies used were apology and regret, explanation, offer of repair, equal - equal, low high and responsibility.

Qanbar (2012:999) in his study which investigated the compliment behavior in the Yemeni speech community suggested that a compliment in Yemeni society is formulaic and commonly contains adjectives. Women are more dominant in using compliment in their communication.

A study of Egyptian Arabic was done by Morsi (2010:51) who examined the speech act of thanking within native speakers of Egyptian Arabic who lived in the city of New York. The research locations were places where they usually interact with, such as shops, clinics, and homes. The study concluded that the functions of the thanking expressions in Egyptian Arabic include appreciation of benefit, opening and close a conversation, and leave-taking.

Several studies that have been conducted regarding the Arabic language have not shown cooperative patterns that are formed from speech events happened in the Arab society. Therefore, the cooperative patterns in the Egyptian speech events characterized this study.

Clauses, sentences, and paragraphs of Egyptian Colloquial Arabic (Amiyah) which were used as a means of communication by the Egyptians, especially those living in Cairo and Ismaili, were used as research data. The data were collected through interviews (participatory observation) using recording and note-taking techniques. To determine the cooperative patterns formed by the speaker and hearer, this study employed the theory of pragmatics, a branch of Linguistics that studies the language in social contexts, and how the contexts contribute to comprehend meanings (Verhaar, 2001:14). Meanwhile, Leech (1993:8) defines pragmatics as the study of how utterances have meanings in situations.

By employing Grice's theory of cooperative principles (1975:45-47), the collected data were analyzed by taking into account cooperative patterns that exist between speaker and hearer. The results of the data analysis were presented in the form of ordinary words using the scientific language variety.

\section{COOPERATIVE PATTERNS}

A conversation leads to the equalization of elements on the formerly different cooperative transaction (Grice, 1975: 309). The equalization is done by way of: (1) equating short-term goal, even though the end goal is different or even contradictory, (2) uniting participation contribution so that the speaker and the hearer need each other, and (3) trying to make the speaker and the hearer have a common understanding that the transaction occurs with a certain compatible pattern.

Grice (1975: 45-47) outlines the cooperative principles in four maxims, i.e. the maxim of quantity, the maxim of quality, the maxim of relation, and the maxim of manner. According to Grice, the maxim of quantity requires the speaker to make an adequate contribution or as much as is required by the hearer. The maxim of quality compels each interlocutor to say something true and based on adequate evidence. The maxim of relation demands a cooperation between the speaker and the hearer in which each interlocutor should give a relevant contribution to the conversation topic. The maxim of manner requires each interlocutor to speak in direct way by avoiding ambiguity and exaggerated conversation.

The Egyptian conversations using Amiyah Arabic create certain patterns. Based on Grice's (1975) maxims, cooperative patterns among the Egyptians are as follows.

\section{The Maxim of Quantity}

The maxim of quantity requires the speaker to give a sufficient contribution in a conversation. The response should be in line with what is expected and not exceeds what is required. The example below is taken from two Egyptians' conversation: 
(1)

$$
\begin{aligned}
& \text { (أ): أودة فردي ولا عائلة } \\
& \text { (ب): فردي }
\end{aligned}
$$

$\begin{array}{ll}A & : \bar{U} d a h \text { fardī wa lā 'e:'ilah? } \\ B & : \text { Fardī }\end{array}$

A : 'Single room or family room?'

B : 'Single room.'

In the conversation (1), the speaker, who is a hotel receptionist, asks the hearer, who is a hotel guest, about the type of room that he is going to rent. The guest gives an answer to the question, no more and no less by answering "fardi:" (single). The cooperative pattern which is formed in this conversation is consistent with the maxim proposed by Grice (1975). A different cooperative pattern is illustrated in the following conversation:

(2)

$$
\begin{aligned}
& \text { : تاريخ إيه؟؟ }
\end{aligned}
$$

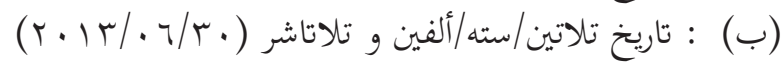

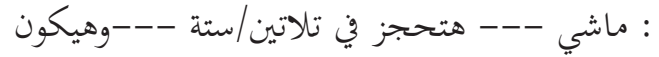

$$
\begin{aligned}
& \text { معاد السفر بتاعك الساعة تمانية بليل }
\end{aligned}
$$

A : Tārik $>$ he êh?

$B \quad:$ Tārìkh talātīn, sittah, alfēen wa talātasyr.

A : Māsyī hatihgiz fì talātīn, sittah, wa hayikūn ma 'àdus-safar bitā'ak il-sā'ah tamāniyah bileil.

A : 'What date?'

B : 'The thirtieth of June 2013'

A : 'Okay, it will be available for June 30. You departure time will be eight o'clock.'

The conversation (2) is made by a ticket agent and a customer. When the ticket agent asks about the date, the customer answers "Tärīkh talätīn, sittah" (the $30^{\text {th }}$ of June). The ticket agent responses that the ticket is available for that date by saying "Māsȳ hatihgiz fì talātīn, sittah", then she adds "wa hayikūn ma 'ädus-safar bitā'ak ilsā 'ah tamanniyah bileil". The ticket agent then mentions the availability of the ticket as well as the time of departure. This shows that the ticket agent contributes more than is required by her customer. When the customer asks if the ticket for the $30^{\text {th }}$ is still available or not, the ticket agent (hearer) provides another information that is not expected by the customer, which is 'the time of departure'. This is actually a form of politeness made by the travel agent who is in charge of providing information as complete as possible to her customers. Thus, the cooperative pattern in conversation (2) is in contrast to that in conversation (1) because the hearer responds excessively to speaker's question.

\section{The Maxim of Quality}

The maxim of quality requires the speaker to not say something he or she believe to be false or have no strong and sufficient evidence. The following conversation can be seen as an example of the maxim of quality as proposed Grice (1975: 45-47).

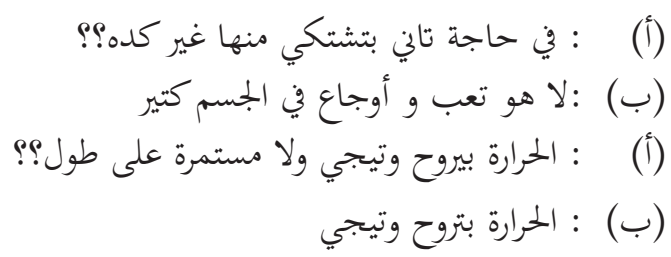

: Fī hạgah tānī bitisytikī minhā ger kedah?

: Là huwa ta 'b wa awgā'fi al-gism kitīr

: Al-harārah biyirūh wi tīḡ̄ wallā mustamirah 'ala tūl?

: Al-harārah biyirūh wi tīḡ̄

A : 'Is there something you are complaining of?'

B : : 'No, just tired and sore in my body.'

A : 'Fever comes and goes, or comes continuously?'

B : 'Fever comes and goes.'

The conversation (3) occurs between a doctor (a) and a patient (b). The patient seesthe doctor, complaining of his fever. When the doctor asks about his complaints "bitisytikī minhā ger kedah", the patient (b) responses appropriately by giving a clear answer according to the fact that his body aches and he has a fever by saying "huwa 
ta'b awgā' fi al-gism kitīr'. Similarly, when the doctor asks about the type of the fever "Al-harärah biyirūh wi tīḡ walla mustamirah 'ala țūl?", the patient givesan answer according to what he is suffering from at that moment by saying "alharāarah biyirūh wi tīg $\bar{\imath}$ ". A different cooperative pattern is illustrated in the following conversation.

(4)

$$
\begin{aligned}
& \text { : أنا كلت دلوقت بس أنا عاوزة كيلو كفتة و فرختين } \\
& \text { عايزة أخذهم تيك أواي } \\
& \text { (ب) : : مش عنيه بس ده هيستني شوية } \\
& \text { خلاص مش مشكلة : } \\
& \text { (ب) : إنتي قلتي قبل ما كنت تقعدي كنت خلصتهم }
\end{aligned}
$$$$
\text { A }
$$

: Ana kult dilwa'ti bas ana 'āyizah kīlo kuftah wa ferkheten wa 'āyizah akhazhum tikk away

$B \quad$ : Musy 'inah bas dih hastani syuwayyah

A : Khalāṣ musy musykilah

B : Intī ultī abla ma kunti ta' 'adī kuntu khalasthum

A

: 'I just said, I want to eat now. But I will take a kilo of kuftah and 2 chickens home.'

B : 'No problem, but you need to wait awhile.'

A : 'Okay, no problem.'

B : 'You say now. Before you sit down again, I'll finish serving up.'

In the conversation (4), a person buys food in a restaurant to eat at the restaurant. Once finishing eating, he just remembers that he will also order food to take home. Therefore, he goes to the desk to order food to take home. The waiter says okay but the buyer has to wait awhile "Musy 'inah bas dih hastani syuwayyah". Then the waiter adds, "Intī ultì abla ma kunti ta' 'adī kuntu khalasthum" (in a very short time, before you re-sit, the food will be readily wrapped). In fact, the ordered food is available a few minutes later. The following conversation (5) has a different cooperative pattern from the conversations (3) and (4).

$$
\text { ( مافي حلو كده ---- هتاخذ كام مني؟ }
$$

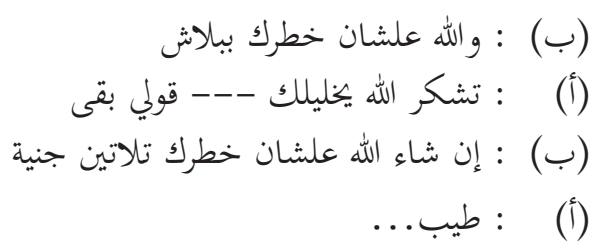

A : Māfì hilü kidah, hata'khudz kēm minnī?

$B \quad$ : Wallāhi 'alasyān khuṭrak bibalāsy

A : Tisykur allāh yukhalīlik ülı̀ ba' $a \bar{~}$

B $\quad:$ In syā allah 'alasyān khutrak talatīn gineh

:Teyb...

A : 'The trip would be nice, right. How much should I pay?

B : 'By Allah, because for you, it's free.'

A : 'Thank you, may God bless you. Just say it.'

B : 'Insha Allah because for you, it's thirty pounds'

A : 'Okay...'

This conversation happens between a person who is going to ride a boat on the Nile and a boatman. When the passenger (the speaker) asks about the cost, the boatman says that he eliminates the cost by saying "wallāhi 'alasyān khutrak bibalāsy". Nevertheless, after the passenger says "tisykur" (thank you), the boatman then says the cost of the boat ride on the Nile is 30 pounds by saying "In syā allah 'alasyān khutrak talatīn gineh". After the boatman mentions the cost, the passenger pays for it. In this conversation, the hearer at first says something that does not correspond to reality - the boat ride on the Nile is not free. In fact, every passenger who rides a boat on the Nile will be certainly charged. However, after that the boatman revises that the cost for a boat ride is 30 pounds.

\section{The Maxim of Relation}

In order to create a good cooperation between speaker and hearer, each should be able to make a relevant contribution to the conversation topic. The example is illustrated in the following conversation:

(6)

$$
\text { : أنا بقالي دلوقت حوالي أسبوع عندي صداع و زوري }
$$




$$
\begin{aligned}
& \text { تاعبني و فيه سخونة و زكام } \\
& \text { (ب) : هو حضرتك قاعد في تكييف أو كده؟؟ فيه ندام }
\end{aligned}
$$

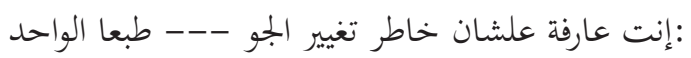

$$
\begin{aligned}
& \text { شوية يكون الجو برد وشوية حر ---- و الواحد } \\
& \text { بيستهوي }
\end{aligned}
$$

A : Ana ba'àlī dilwa't hawā̄lì usbū' 'andī șuda' ' wa zūrī tā 'ibnī wa fìhi sukhūnah wa zukām

B : Huwa hadratak à'id fi takyīf au kedah?

A :Inti 'ārifah 'alasyān khātir tagȳ̄r algaww...tab'an al-wāhid syuwaiyah yikūn al-gaww bard wa syuwaiyah harr...wal wāhid biyistahwi

A : 'Since last week I've had a headache with fever and cough'

$\mathrm{B} \quad$ : 'Are you working in a room with $\mathrm{AC}$ or what?'

A : "You certainly know that there is a problem with the weather, the air changes into cold and hot intermittently. Some people are also disturbed...'

The conversation occurs between a doctor and a patient. When the doctor asks the patient whether he is working in an air conditioned room "huwa hadratak à'id fì takyiff au kedah?", the patient gives an irrelevant answer by saying "inti 'ārifah 'alasyān khātir tagyīr al-gaww...tab'an al-wāhid syuwaiyah yikūn al-gaww bard wa syuwaiyah harr". The patient says that there are some people who are also disturbed by the extremely changing weather, meaning that his pain is not because he is working in an air conditioned room, but because he is disturbed by the extreme weather "inti 'arifah 'alasyān khātir tagyīr al-gaww...tab'an al-wāhid syuwaiyah yikūn al-gaww bard wa syuwaiyah harr...wal wāhid biyistahwi".

Sometimes an interlocutor's contribution is not directly seen from his/her utterances, but on certain things that imply a speech. Responses that are not relevant to the speaker's utterance sometimes also produce a different cooperative pattern, including the following conversation (7).
(7)



: Kuhl...āh...maugūd...ma'as kēm...ya'nī șugayyar wallā kibīr?

B : 'àyizah illīhuwa murabba'... 'ayizāhā murabba' musy laff

A : 'Dark blue. Yes, available. What size? Small or large?

B : 'I would like the rectangle one, not the wrapped one'

This conversation happens between a person who is going to buy a hijab and a seller. When the seller asks the buyer what size she wants "ma 'as kēm...ya 'nī șugayyar wallā kibīr?", she makes an irrelevant contribution to the seller's question by saying “ '... 'ayizāhā murabba' musy laff". The seller (speaker)actually expects her buyer to mention a size by saying "șugayyar" or “kibīr", but she replies 'rectangular' ( 'àyizah illī huwa murabba). The same cooperative pattern is demonstrated in the conversation (8) below.

(8)

$$
\begin{aligned}
& \text { : الأزهر طيب لو جيت أروح --- أسأل هناك أركب } \\
& \text { إيه حضرتك } \\
& \text { (ب) : جامعة الأزهر في مدينة نصر }
\end{aligned}
$$

A : Al-azhar tayb lau gìt arūh....as'al hināka arkab īh hadratak

B : Gāmi 'atil-azhar fi madīnat nașr

A : 'Al-Azhar. If you are going to the campus right now, let's go together. What transportation can we use to go there?'

B : 'Al-Azhar University is in Nasser City.'

The conversation(8) occurs between a prospective student seeking information about al-Azhar University and an Al-Azhar student. The prospective student asks the Al-Azhar student how to get to Al-Azhar University "as'al hināka arkab 
ìh". The Al-Azhar student gives an unsuitable response to the question by saying the university is located in Nasser City"Gämi 'atil-azhar fī madīnat nașr". In term of Grice's (1975) maxim of relation, the interlocutor (student) provides an irrelevant response to speaker's question. The response is said to be relevant when he responds by mentioning a type of transportation to get to Al-Azhar University.

\section{The Maxim of Manner}

The maxim of manner requires each interlocutor to speak briefly and orderly by avoiding ambiguity and exaggerated obscure conversation. The following conversation (9) happens between a father and a government official.

$$
\begin{array}{ll}
\text { A } & : \text { Muddah ad-dirāsah bitākhuż fì ēh?? } \\
B & : \text { Huwa hadratak hadakhalhum kulliyāt } \\
& \bar{e} h ?
\end{array}
$$

A : 'How long will the study last?'

B : 'What faculty will your son be attending?'

A father who is going to send his son to a university abroad goes to a government office to take care of the necessary documents. When the father asks about the period of study "Muddah addirāsah bitākhuż fi èh??", the government official responds by making a question "Huwa hadratak hadakhalhum kulliyāt èh?", thus causing the conversation ambiguous. This happens because the interlocutor intends to give an appropriate answer to the speaker's question, given that the study period for each faculty is different. A different cooperative pattern is illustrated in the following conversation (10):

$$
\begin{aligned}
& \text { : طيب حضرتك إن شاء الله هتعلمهالي بكام؟؟ } \\
& \text { (ب) : بميت جنية الفرد }
\end{aligned}
$$

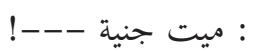

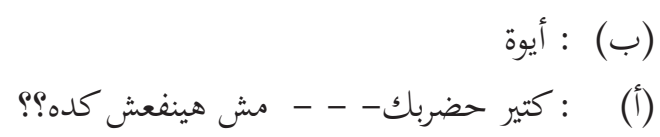

$A$

: Tayb hadratak insyaAllah hati 'milhā $l \bar{l}$ bikām

: bimīt gineh il-fard

: Mìt gineh...

: Aiwah

: Tayb kitìr hadratak...musy hayanfa'sy kedah??

A : 'So, how much I have to pay?'

B : 'One hundred pounds for one person'

A : 'One hundred pounds?'

B : 'Yes'

A : 'That's too much. For what? It's pointless then.'

The conversation (10) happens between a travel agent and a customer. When the customer asks about the cost of a travel package to Alexandria "insyaAllah hati 'milhā li bikàm", the travel agent answers "bimit gineh il-fard" (one hundred pounds for one person). To ensure that he hears the correct answer, the customer repeats the travel agent's answer "Mìt gineh?" (one hundred pounds?), and the travel agent replies "Aiwah" (yes). The speaker who has received a clear answer objects to the offered price by saying "musy hayanfa'sy kedah" (that's too much). For the interlocutor, this causes an obscurity of meaning.

\section{COOPERATIVE PATTERNS IN SOME SITUATIONS}

In some expressions, there are some cooperative patterns produced by the speakers and the hearers. The cooperative patterns produced in certain situations are diverse. Here are some examples of cooperative patterns that are produced by speakers and hearers in some situations.

\section{Compliment}

A compliment is defined as a speech act which explicitly or implicitly attributes credit to someone other than the speaker, usually the speaker addressed, some for 'good' (possession, 
characteristic, skill etc.) which is positively valued by the speaker and the hearer (Holmes, 1988:458). Conversation in Egyptian Arabic commonly uses compliments, which one of its intention is for mujamalah. The conversation below contains a compliment.

$$
\begin{aligned}
& \text { : أهلا و سهلا ـ العمر كام }
\end{aligned}
$$

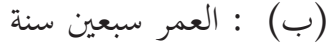

$$
\begin{aligned}
& \text { : ما شاء الله --- يهديك الصحة و العافية. }
\end{aligned}
$$

$\begin{array}{ll}\text { A } & \text { : Ahlan wa sahlan. al-'umr kām } \\ B & : \text { Al-'umr sab'in sanah } \\ A & : \text { Maa syaa'Allah...yihdīka aș-șihah wal- } \\ & \text { 'äfyah }\end{array}$

A : 'Welcome. How old are you?'

B : 'I am 70 years old.'

A : 'MashaAllah, God bless you with health and goodness.'

The speaker, who is a doctor, asks his patient how old is he "al- 'umr kām?", then the patient replies that he is 70 years old "al- 'umr sab'in sanah". The hearer (patient) contributes in accordance with the speaker's (doctor) question. After the patient gives his answer, the doctor compliments him on his long life as blessed by God " $m \bar{a}$ syā'Allah... yihdīka aș-șihah wal- 'áfiyah". The doctormakes a relevant contribution to the patient's answer by complimenting him on his longevity. Thus, the communication between them goes well. Each speaker and hearer makes a sufficient contribution which is in line with the fact, and there is relation between the speaker and the hearer.

\section{Thanking}

Egyptian Arabic speakers use different forms and strategies in expressing thanking and responses to it, such as repetition, redundancy and plenty of formulaic expressions such as blessings and prayers in order to show sincerity and gratitude to the hearer (Morsi, 2010:5). Thus, the pattern formed by thanking expression is varied, including a cooperative pattern between an Egyptian student and her friend as follows.
(12)

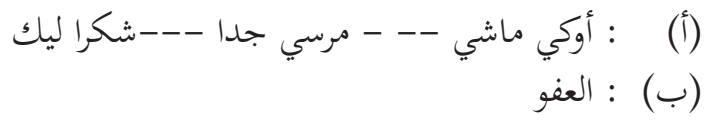

A : Ukē māsyī...mercy gidan ...syukran lēk $B \quad: A l-' a f w$

A : 'Okay, thank you.'

B : 'You are welcome.'

A prospective student thanks her friend after giving her important information about study at al-Azhar University "mercy gidan...syukran lekk". The hearer, who is an al-Azhar student, gives an adequate response by replying " $A l$ - ' $a f w$ ". The cooperative pattern formed from the conversation shows that each speaker and hearer gives a relevant contribution, in which the speaker responses appropriately by saying 'thank you'. The hearer's response is not excessive, so it does not result in the obscurity of meaning.

Another cooperative pattern in thanking is shown in the following conversation.

$$
\text { (ب) : : : ماشي --- شكرا }
$$

A : $m \bar{a} s y \bar{\imath} \ldots$ syukran

$B \quad$ :Al 'afwu' al ēh?

A : 'Okay, thank you.'

B : 'What for?'

The conversation (13) is the end of a conversation between a doctor and hispatient. After examining and prescribing his patient, who is older than him, the doctor thanks his patient for visiting him "māsyī... syukran". However, the patient gives an irrelevant contribution and causes an obscurity by responding "Al 'afwu 'al èh?". The patient actually expresses his politeness because he thinks that the one who is supposed to thank is him (not the doctor)since he has been examined by the doctor. 


\section{Apology}

Al-Abdi (1981:4-5) defines apology as the utterances and deeds a person tries to offer to lift punishment or blame due on him/her for a malicious deed he has committed. In Arabic communication, apology is expressed in some situations. The conversation below illustrates an apology in Arabic communication.

$$
\begin{aligned}
& \text { : كده متين خمسة و عشرين و الجوانب بعشرة و } \\
& \text { الحاجات الباقية بعشرة يبقى تلاتين --- يبقى كله } \\
& \text { متين خمسة و خمسين } \\
& \text { (ب) : طيب ممكن خمسة وخمسين }
\end{aligned}
$$

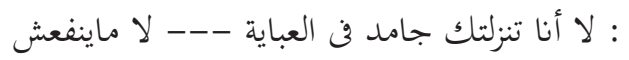

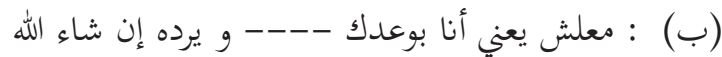



$$
\begin{aligned}
& \text { : لا لا لأه مش هينفع يكون لك خلك خمسة جنيه كده لا لا } \\
& \text { (ب) : بيفع أنا هنزلك كتير } \\
& \text { : معلش مش هجبي حاجة لو أخذات متركير متين و خمسين: } \\
& \text { جنية } \\
& \text { (ب) : علشان حضرتك بحب لي مرة تانية }
\end{aligned}
$$

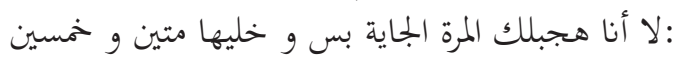

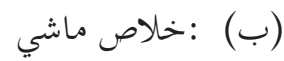

\begin{tabular}{|c|c|}
\hline$A$ & $\begin{array}{l}\text { Kedah mitīn khamsah wa 'isyrīn wal- } \\
\text { gawanti bi 'asyrah wal-hāgāt al-bāiyah } \\
\text { bi 'asyrah yib'a talātīn---yib'a kulluh } \\
\text { mitìn khamsah wa khamsīn }\end{array}$ \\
\hline$B$ & Tayb mumkin khamsah wa khamsin \\
\hline$A$ & $\begin{array}{l}\text { Là ana tinziluka gāmid fil-'abāyah...lā } \\
m \bar{a} \text { yanfa'sy }\end{array}$ \\
\hline$B$ & 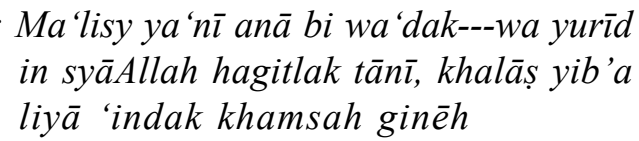 \\
\hline$A$ & $\begin{array}{l}\text { Là lā la'ah, musy hayanfa'sy yikūn liki } \\
\text { khamsah gineh kedah là yanfa'sy }\end{array}$ \\
\hline$B$ & Hā ana hananziluki kitīr \\
\hline$A$ & $\begin{array}{l}\text { Ma 'lisy musy hagībì hạgah lau akhażtu } \\
\text { mitīn wa khamsin gineh }\end{array}$ \\
\hline$B$ & $\begin{array}{l}\text { 'alasyān hadratak tagib lì marrah } \\
\text { tāniyah }\end{array}$ \\
\hline & Là ana hagabalak al-marah al \\
\hline
\end{tabular}

\section{wa khalīhā mitīn wa khamsīn}

: Khalāṣ māsyzi

A : 'That's 225 pounds. 10 pounds for the gloves, and the others are each ten, so it's thirty. So, that's 255 pounds altogether then.'

B : 'Fine, how about 250 pounds?'

A : 'No. I'll lower the price for abaya only.

B : 'I'm sorry. I promise I'll come again. Well. I just cut 5 pounds off.

: No. 5 pounds is not worth.'

: 'I just give you much price cut.'

: 'Sorry, I'll give you 250 pounds for all these.'

: 'But you must come again.'

: 'Yes, I will. I'll payyou 250 pounds.

: 'Alright.'

The above conversation occurs between aclothes seller and a buyer. To geta final price, the seller and the buyer make a negotiation. The seller insists onthe price she sets(255 pounds) "yib'a kulluh mitīn khamsah wa khamsin", butthe buyer wants a lower price (250 pounds) "mumkin khamsah wa khamsin". Each speaker and hearer contributes adequately in the conversation. However, because the buyer has not got the price she wants, then the buyer says ma 'lisy say 'sorry' with the intention to make the seller accept her proposed price. In term of cooperative pattern, the partner (buyer) does not give a relevant contribution to the speaker's utterance (offering). Obviously, the partner has a specific purpose of saying 'sorry'. In Arab society, an apology is often spoken by women to obtain a compensation (Muzhir, tt:74). This is also done by the buyer to get a rebate. Making an apology to the hearer means the speaker lowers her/his status below the hearer. However, this speaker's lower status will cause the hearer to follow his/her want so that the negotiation could reach an agreement.

\section{Negotiation}

In a negotiation process, the speaker and the hearer forms a cooperative pattern which produces an agreement between the two. In Egyptian society, negotiation often takes a long process. In the negotiation process, the speaker and the hearer frequently perform perlocutionary 
acts, which Austin (1962:101) defines as "what we bring about or achieve by saying something, such as convincing, persuading, deterring, and even, say, surprising or misleading". A perlocutionary act is associated with specific effects expected by the speaker's utterances(Baskoro, 2014: 82). The conversation below demonstrates a process of negotiation between a taxi driver and his passenger in determining a taxi fare.

$$
\begin{aligned}
& \text { :أيوة هنا هتزل هنا ----كام؟؟ } \\
& \text { (ب) : أمسين جنيه }
\end{aligned}
$$



$$
\begin{aligned}
& \text { (ب) : :والله إنت ضيعنا وقت أد إيه ---- خلهم خمسة و } \\
& \text { أربعين : } \\
& \text { لا هما أربعين جنية بس } \\
& \text { (ب) :ماشي آر (1) }
\end{aligned}
$$

A : Aiwa hinā hatinzil hinā kem?

$B \quad:$ Khamsing ginēh

A : Dā kibīr, arba'īn ginēh bas.

B : Wallāh inti dayya'na wa't adi èh, khilhim khamsah wa arba'īn

A $\quad:$ Là humā arba'ìn gineh bas

$B \quad: M \bar{a} s y \bar{\imath}$

A : 'I get out here. How much is that?'

B : 'Fifty pounds.'

A : 'That's too much.Forty pounds.'

B : 'By Allah, you see, we've spent a long time.Come on, pay only 45 pounds.'

A : : 'No, I'll pay you forty pounds.'

B : 'Okay.'

A passenger takes a taxi to go tothe city of Doki. After arriving, she asks about the fare. The taxi driver says 50 pounds "khamsin ginēh". The passenger bargains it down to 40 pounds " $d \bar{a}$ kibìr, arba'in ginēh bas". The negotiation process continues when the taxi driver does not agree with the reduction because of the crowded and long journey. For that reason, he asks for 45 pounds "dayya'na wa't adi èh, khilhim khamsah wa arba ' $\bar{n}$ ". Thinking that it is too expensive, the passenger insists on 40 pounds "là humā arba' 'in gineh bas". Realizing that his reason does not affect the passenger, the taxi driver then accepts the proposed cost reduction.

\section{Interrupting}

One of the Arabs habits in conversation is interrupting. This gives rise to an impression that the hearer cannot wait to respond to the speaker's utterance. The conversation (6) between a doctor and a patient above describes such a situation. At first, the doctor asks if his patient works in an airconditioned room. Then the patient says that the weather changes so often, making some people disturbed. Before the patient finishes his utterance, the doctor interrupts him. In this situation, it is assumed that the doctor thinks that the patient does not give a proper contribution to his question. The doctor actually expects 'yes or no' answer. Because of not getting a proper response, the doctors reexplains by giving an example that the patient sleeps in a very cold room because he forgets to turn off the air conditioner before leaving the room. Another example of interrupting is as follows (16):

$$
\begin{aligned}
& \text { : أي بلد ممكن تبعثهم----؟؟ }
\end{aligned}
$$

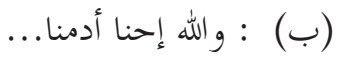

$$
\begin{aligned}
& \text { : اللي أكتر أمان يعني؟؟ :ألنا } \\
& \text { (ب) : إحنا أدمنا بجموعة بلاد ---- بس أنا أفضن أفضك هولندا }
\end{aligned}
$$

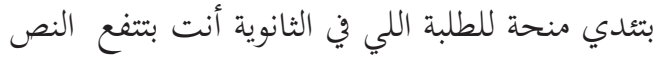

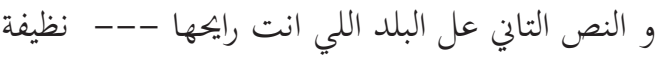

$$
\begin{aligned}
& \text { قوي.... واحد مرشد و يبقلهم و كده و بيبقوا الولاد النياد التها }
\end{aligned}
$$

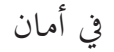

A : Iy balad mumkin tib 'as $\mid$ hum??

B : Wallāhi ihnnā udamnā...

A : Illī aktar amān ya 'n̄̄??

B : Ihñā udamnā magmū'ah bilād...bas ana afadhallak Hūlandā biti'dī minhah littalabah as|-s|ānawiyyah anta bitidfa'ennuṣ wen-nuṣ at-tāñ̄ 'alal-balad illiy inta rāyihhāa...nazhīfah awī...wāhid mursyid wa yib'alhum wa kedah wi biyib'ü alwalād fì amān

A : 'To which country you are going to send them?' 
B $\quad:$ 'We will present ...'
B $\quad:$ 'To the safest country?'
$\quad$ : 'We will present some countries. I
usually provides cost relief to high
school students. You will pay a half first,
and the remaining half will be paid in the
country you choose. The Netherlands is

very clean. All international students
gets one guide so that they are safe.'

The conversation occurs between a man and a government official. The man asks about a country where the official usually sends students abroad "Iy balad mumkin tib 'as $\mid$ hum? ”. The officials says that he is going to present some countries that usually become a destination for study. But before the official finishes explaining, the man interrupts him, so that the official stops talking "wallāhi iḥnā udamnā...". The man does so since he thinkshe has to clarify his question with the intention to receivea sufficient contribution (answer), which is information about the safest country for study "illi aktar amān ya 'n̄̄?".

\section{CONCLUSION}

The speech events that occur among Egyptian Colloquial Arabic (Amiyah) speakers create a variety of cooperative patterns. In these varied cooperative patterns, the speakers give not only relevant contributions to the speakers' utterances, but also irrelevant contributions. By employing Grice's view of the conversation maxims, this study suggests that speech events in Egyptian society has various cooperative patterns.

The varied cooperative patterns can be shown in the negotiations to reach an agreement. In a speech that is intended to reach an agreement, the speaker and the hearer mutually to make an excessive and less relevant contribution. In Arab society, an apology is often made by women to get a compensation, so that negotiation reaches an agreement.

The habit of interrupting the other is intended to make the hearer provide a sufficient contribution to the speaker's speech. This happens when the speaker thinks that he or she does not receive a relevant and adequate contribution from the hearer. These two things are very dominant in
Egyptian society's communication. Consequently, a negotiation requires a lot of energy and time to reach an agreement.

\section{ACKNOWLEDGEMENT}

This article is based on the research "Peristiwa Tutur Masyarakat Mesir sebagai Penguatan Teori Bahasa Arab di Era Globalisasi dalam Upaya Penguatan Kedaulatan Bangsa" funded by Faculty of cultural sciences, Universitas Gadjah Mada.

\section{REFERENCES}

Al-Abdi, M.O. (1981). A book of pardon and apology. Riyadh: Imam Muhammad bin Saud Islamic University Press.

Austin, J.L. (1962). How to do things with words. London: Oxford University Press.

Bakalla, M.H. (1984). Arabic culture: through its language and literature. London: Kegan Paul International.

Baskoro, B.R.Suryo. (2014). Pragmatik dan wacana korupsi, in Jurnal Humaniora Fakultas Ilmu Budaya UGM Vol. 26 No 1, February 2014.

Greis, Naguib. (2000). Aspects of modern egyptian arabic: its structure, humor, proverbs, metaphors, euphemisms and common expressions. Ttp. Education resources Information Center.

Grice, H. Paul. (1975). Logic and conversation. New York: Academic Press

Holmes, J. (1987). Paying compliments: a sexpreferential politeness strategy. Journal of Pragmatics, 12, 445-465.

Jaradat, Radwan Mahadin Abdulazeez.The pragmatic function of intonation in irbid dialect acoustic analysis of some speech acts. International Journal of Humanities and Social Science Vol. 1 No. 9 [Special Issue - July 2011]

Leech, Geoffrey. (1993). Prinsip-prinsip pragmatik (translated by M.D.D. Oka and Setyadi Setyapranata). Jakarta: Penerbit Universitas Indonesia.

Morsi, Rehab. (2010). The Speech act of thanking in egyptian arabic. MA Thesis in Ball State University of Muncie, Indiana, USA.

Muzhir, Hussein Dhahi, Raheem, Musaab Abdul-Zahra. tt. A socio-pragmatic study of apology in Iraqi non-standard arabic. University of Kufa College of Arts 
Prochazka. S. (2006). "Arabic" in Encyclopedia of language and linguistics 2nd edition (423). London: Elsevier.

Qanbar, Nada. (2012). Compliments in the Yemeni society: a sociolinguistics perspective, in GEMA Online ${ }^{\mathrm{TM}}$ Journal of Language Studies Volume 12(3), September 2012

Al-Sobh, Mahmoud Ali, (2013). An analysis of apology as a politeness strategy expressed by Jordanian University students, in International Journal of Humanities and Social Science Vol. 3 No. 2 [Special Issue - January 2013]

Verhaar, J. W. M. (2001). Asas-asas linguistik umum. Yogyakarta: Gadjah Mada University Press

Wijana, I Dewa Putu. (1996). Dasar-dasar pragmatik. Yogyakarta: Andi Offset

Yule, George. (1996). Pragmatik. Yogyakarta: Pustaka Pelajar 